$\overline{\text { Original }}$

\title{
Bacterial Contamination on Hands after Various Nursing Procedures
}

\author{
YASUKO TAKAHASHI, AKEMI TAKESHITA*, \\ MIYOKO ENDO, AND MINAKO SASAKI \\ Graduate School of Health Sciences and Nursing, Faculty of Medicine, University of Tokyo \\ 7-3-1 Hongo, Bunkyo-ku, Tokyo 113-0033, Japan
}

Received 6 December 2001/Accepted 8 May 2002

\begin{abstract}
The bacterial counts (log cfu/hand) on hands after conducting daily nursing procedures on a long-term hospitalized patient were quantitatively examined by using the wiping method. Since measures such as wearing gloves were taken when heavy contamination was expected in certain nursing procedures, most of the bacterial counts on the hands after various nursing procedures were $2-5$, and the mean was $3.12 \pm 0.80$. The post - procedure hand bacterial counts, however, were different depending on the type of procedure. The hand bacterial

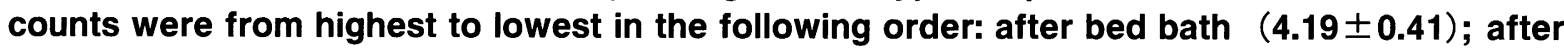
oral care (3.60 \pm 1.31$)$; after diapering (3.48 \pm 0.71$)$; after genital wash (3.20 \pm 0.72$)$; after changing positions $(2.82 \pm 0.51)$; and after endotracheal aspiration $(2.34 \pm 0.57)$. The hand bacterial counts after bed baths, diapering, and genital wash differed depending on the condition of the diaper of the patient, with higher hand bacterial counts on the days with patient defecation, compared to the days without defecation. Based on the above results, it was suggested that the hand bacterial counts after nursing procedures were highest after procedures involving direct contact with the patient's skin (or saliva), lower for procedures in which the patient's clothing, etc., was touched, and lowest for procedures involving no direct contact with the patient.
\end{abstract}

Key words : Bacterial contamination/Nursing procedure/Bed bath/Diapering/Defecation.

\section{INTRODUCTION}

Contamination via hands of hospital personnel is known as one of the causes for the transmission of nosocomial infections. It has been reported that routine nursing procedures cause the nurse's hands to become contaminated due to bacteria from the patient (Casewell and Phillips, 1977). In recent years, a pattern in which hospital personnel, after touching a contaminant, unknowingly spread the contamination to one person after another via contaminated hands, has been examined and clarified as a result of several experiments (Chamberlain et al., 1997; Jiang et al.,

${ }^{*}$ Corresponding author. Tel: +81-3-5841-3524, Fax : +813-5841-3376.
1998). In order to prevent transmission of contaminants by hospital personnel, in particular by nurses, handwashing after patient care is an essential and critical procedure on a daily basis. It is necessary to clarify the relationship between various nursing procedures and bacteria on the hands as well as the types and amount of bacteria, and to consider and suggest an appropriate handwashing method so that the hands of nurses will not serve as the source of contamination.

The detection methods for bacteria on the hands after nursing procedures include the contact plate method and the wiping method. Although the contact plate method has slightly inferior sensitivity regarding the detected bacterial counts, since there is an advantage that samples from the nurses' hands can be 
quickly collected, it is widely used for sampling at clinical sites (Katsuno et al., 1998; Tanada et al., 1996). The authors used the contact plate method for the collection of samples, and made examinations focusing primarily on the kinds of bacteria found after nursing procedures (Takahashi et al., 1994; Takahashi, 1999). However, since there are cases in which an accurate measurement is impossible in places with numerous bacterial counts, we could not quantitatively examine the bacterial counts after nursing procedures. In the meantime, although the wiping method has the advantage that quantitative data can be collected, even when the bacterial counts are high, it takes longer and the method itself, from sample collection to incubation, is complex compared to the contact plate method.

In this study, we quantitatively examined the hand bacterial counts when daily nursing procedures were conducted, with or without nurses wearing gloves, using the wiping method. In addition, in order to predict the cause of bacterial contamination after nursing procedures, we conducted bacterial investigations of the patient and the environment surrounding the patient at the time of the nursing procedures. The results are reported below.

\section{MATERIALS AND METHODS}

\section{Nursing procedure subject}

As a nursing care subject, a long-term hospitalized patient in the medical ward of hospital with no nosocomial infections was chosen. Two nurses performed a variety of daily nursing procedures conducted in the ward including endotracheal aspiration, bed bath, changing positions, diapering, oral care, and genital wash. Furthermore, sterile gloves were worn for the endotracheal aspiration because an aseptic operation is required. In addition, when heavy hand contamination was expected with nursing procedures, such as oral care or genital wash, which involve handling the patient's body fluids or excretions, the nurses wore a pair of gloves before conducting the nursing procedure.

\section{Method for measuring bacteria on the hands}

Samples of the bacteria on the hands after various kinds of nursing procedures were collected from both right and left palms of the nurses using sterilized swabs, using $2 \mathrm{ml}$ of physiological saline as a collection fluid. As for the procedures conducted with gloves, bacteria on the hands were collected from both the right and left palms after the nurses removed the gloves when the nursing procedure was finished. The collected sample was appropriately diluted, smeared into ovine blood agar medium (Nissui Plate Sheep Blood Agar ${ }^{\circledR}$; Nissui Pharmaceutical, Co., Ltd.) and mannitol salt medium with added yolk (Nissui Plate Mannitol Salt Agar with Egg York ${ }^{\circledR}$; Nissui Pharmaceutical, Co., Ltd.). After a 48-h aerobic incubation at $36^{\circ} \mathrm{C}$, bacterial counts were calculated by counting the bacteria.

\section{Method for measuring the bacteria from the envi- ronment and patient}

In order to predict the cause of the bacterial contamination after nursing procedures, bacterial investigations were conducted on the environment surrounding the patient, the patient's skin, and the equipment used for the nursing procedures. Bacteria were collected using the stamp method and the wiping method. Among the samples collected by the stamp method from the patient himself and from the environment surrounding the patient, sheets, pillows used for changing positions, hospital pajamas (surface), diaper (inside), and the patient's palm were sampled at one location each, by using a contact plate (Food Stamp "Nissui" Standard Method Agar ${ }^{\circledR}$ ;Nissui Pharmaceutical, Co., Ltd.). This was followed by a 48 -h aerobic incubation at $36^{\circ} \mathrm{C}$, and bacterial counts were calculated by measuring the bacterial numbers. Sources for the samples collected by the wiping method included the patient's palms, buttocks, and right and left inguinal regions, diaper (inside), towels for bed bath and the toothbrush used for the nursing procedure. Two $\mathrm{ml}$ of physiological saline was used as a collection fluid, and the samples were collected from one location each using sterilized swabs. The sample from the skin was collected from a $2 \times 2$ $\mathrm{cm}^{2}$ area. As for the toothbrush, the sample was collected from a $1 \times 1 \mathrm{~cm}^{2}$ area right before oral care, and the sampling was performed three times on different days. The sample from the bed bath towel was collected from a $2 \times 2 \mathrm{~cm}^{2}$ area, unused before the bed bath. While four towels were used for each bed bath, two were randomly chosen, and four samplings were conducted on different days to collect a total of eight samples. The samples collected by the wiping method were appropriately diluted, smeared onto ovine blood agar medium (Nissui Plate Sheep Blood Agar ${ }^{\circledR}$ ) and mannite salt medium with added yolk (Nissui Plate Mannitol Salt Agar with Egg York $\left.{ }^{\circledR}\right)$. After a 48-h aerobic incubation at $36^{\circ} \mathrm{C}$, the bacterial counts were calculated by counting the bacterial numbers. 


\section{RESULTS}

\section{Comparison of the hand bacterial counts depend- ing on the type of nursing procedure}

Figure 1 shows all the data on the hand bacterial counts after various nursing procedures, and Table 1 shows the mean \pm S.D. of the hand bacterial counts after nursing procedures. The total number of samples collected from the hands after nursing procedures, $n$ is 208, with the following breakdown: changing positions, 68; diapering, 68; endotracheal aspiration, 36; bed bath, 12; genital wash, 12 , and oral care, 12. The minimum value of the hand bacterial counts (log cfu/hand) among all the samples was 1.30 after endotracheal aspiration and oral care, the

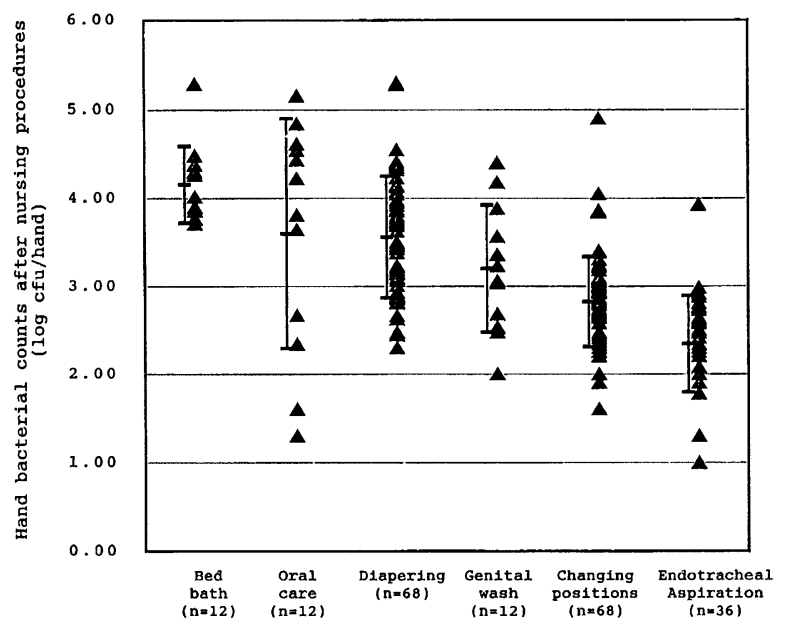

FIG. 1. Hand bacterial counts after nursing procedures. Symbols : $\mathbf{\Lambda}$, Value of hand bacterial counts after nursing procedures. Mean values and S.D. values are indicated with intermediate horizontal lines and vertical lines inserted.
TABLE 1. Hand bacterial counts after nursing procedures.

\begin{tabular}{|c|c|c|}
\hline $\begin{array}{c}\text { Type of } \\
\text { nursing procedure }\end{array}$ & No. of samples & $\begin{array}{l}\text { Mean士S.D. } \\
(\log \mathrm{cfu} / \mathrm{hand})\end{array}$ \\
\hline Changing positions & 68 & $2.82 \pm 0.51$ \\
\hline Diapering & 68 & $3.48 \pm 0.71$ \\
\hline $\begin{array}{l}\text { Endotracheal } \\
\text { aspiration }^{a}\end{array}$ & 36 & $2.34 \pm 0.57$ \\
\hline Bed bath & 12 & $4.19 \pm 0.41$ \\
\hline Genital wash ${ }^{b}$ & 12 & $3.20 \pm 0.72$ \\
\hline Oral care ${ }^{c}$ & 12 & $3.60 \pm 1.31$ \\
\hline $\begin{array}{l}\text { Total number } \\
\text { of samples }\end{array}$ & 208 & $3.12 \pm 0.88$ \\
\hline
\end{tabular}

${ }^{a} \mathrm{~A}$ glove was worn on the right hand.

${ }^{b}$ Gloves were worn on the right and left hands.

${ }^{c}$ There are both cases in which gloves were worn $(n=2)$ and gloves were not worn $(n=10)$.

maximum value being 5.30 after diapering, and the mean \pm standard deviation of all the samples was 3.12 \pm 0.80 . According to Scheffe's multiple comparison test on hand bacterial counts after nursing procedures, a significant difference in values was found depending on the type of nursing procedure performed (Table 2). The hand bacterial counts after nursing procedures were from highest to lowest in the following order: after bed baths, oral care, diapering, genital wash, changing positions, and endotracheal aspiration. Furthermore, genital wash required wearing gloves on both hands, but greater bacterial counts on the hands were found after that procedure than after changing positions, which was conducted without gloves.

In addition, there was no sample from a colony or its surrounding area which showed response on the mannite salt medium with added yolk in this test, and

TABLE 2. Statistical significance by Scheffe's multiple comparison test.

\begin{tabular}{|c|c|c|c|c|c|c|}
\hline \multirow{2}{*}{$\begin{array}{l}\text { Type of } \\
\text { nursing } \\
\text { procedure }\end{array}$} & \multicolumn{6}{|c|}{ Type of nursing procedure } \\
\hline & $\begin{array}{c}\text { Endotracheal } \\
\text { aspiration }\end{array}$ & $\begin{array}{l}\text { Changing } \\
\text { positions }\end{array}$ & $\begin{array}{c}\text { Genital } \\
\text { wash }\end{array}$ & Diapering & Oral care & $\begin{array}{l}\text { Bed } \\
\text { bath }\end{array}$ \\
\hline $\begin{array}{l}\text { Endotracheal } \\
\text { aspiration }\end{array}$ & - & - & - & - & - & - \\
\hline $\begin{array}{l}\text { Changing } \\
\text { positions }\end{array}$ & $p<0.05^{a}$ & - & - & - & - & - \\
\hline Genital wash & $p<0.05$ & N.S. ${ }^{c}$ & - & - & - & - \\
\hline Diapering & $p<0.001^{b}$ & $p<0.001$ & N.S. & - & - & - \\
\hline Oral care & $p<0.001$ & $p<0.05$ & N.S. & N.S. & - & - \\
\hline Bed bath & $p<0.001$ & $p<0.001$ & $p<0.05$ & N.S. & N.S. & - \\
\hline
\end{tabular}

${ }^{a}$ Statistically significant at $5 \%$.

${ }^{\circ}$ Statistically significant at $0.1 \%$.

'Not significant. 
TABLE 3. Hand bacterial counts for both right and left hands after nursing procedures.

\begin{tabular}{cccc}
\hline $\begin{array}{c}\text { Type of } \\
\text { nursing } \\
\text { procedure }\end{array}$ & $\begin{array}{c}\text { Right hand } \\
\text { (log cfu/hand })\end{array}$ & $\begin{array}{c}\text { Left hand } \\
\text { (log cfu/hand) }\end{array}$ & $\begin{array}{c}\text { Statistical } \\
\text { significance }\end{array}$ \\
\hline Changing & $\begin{array}{c}2.84 \pm 0.51 \\
(n=34)\end{array}$ & $\begin{array}{c}2.80 \pm 0.52 \\
(n=34)\end{array}$ & N.S. ${ }^{a}$ \\
positions & $\begin{array}{c}3.49 \pm 0.72 \\
(n=34)\end{array}$ & $\begin{array}{c}3.46 \pm 0.71 \\
(n=34)\end{array}$ & N.S. \\
Diapering & $2.34 \pm 0.54$ & $2.35 \pm 0.58$ & N.S. \\
Endotracheal & $(n=18)$ & $(n=18)$ & N.S. \\
aspiration & $\begin{array}{c}4.26 \pm 0.56 \\
(n=6)\end{array}$ & $\begin{array}{c}4.05 \pm 0.27 \\
(n=6)\end{array}$ & N.S. \\
Bed bath & $\begin{array}{c}3.05 \pm 0.65 \\
(n=6)\end{array}$ & $\begin{array}{c}3.35 \pm 0.82 \\
(n=6)\end{array}$ & N.S. \\
Genital wash & $\begin{array}{c}4.03 \pm 1.28 \\
(n=6)\end{array}$ & $\begin{array}{c}3.17 \pm 1.29 \\
(n=6)\end{array}$ & \\
Oral care & & &
\end{tabular}

${ }^{a}$ Not significant.

no bacterium that appeared to be Staphylococcus aureus among the bacteria found on the nurses' hands after the nursing procedure.

\section{Comparison of the left and right hand bacterial counts}

Table 3 shows the mean \pm standard deviation of the hand bacterial counts for both right and left hands after nursing procedures. For oral care, a tendency was found in which there were greater bacterial counts on the right hand compared to the left, but according to the result of the Mann-Whitney test, no significant difference was found in the bacterial counts on both hands for any of the nursing procedures. Furthermore, endotracheal aspiration was conducted with a glove on the right hand and without one on the left at the time of the nursing procedure, but no significant difference in hand bacterial counts between the two hands was found in this test.

\section{Comparison of hand bacterial counts depending on the day of the procedure}

The sampling in this investigation was conducted on six separate days. Table 4 shows the mean \pm standard of the hand bacterial counts depending on the day when the procedure was conducted. According to Scheffe's multiple comparison test, a significant difference was found in the hand bacterial counts depending on the day (Table 5).

\section{Comparison of hand bacterial counts depending on the day and type of nursing procedure}

Table 6 shows the mean \pm standard deviation of the hand bacterial counts depending on the day, after endotracheal aspiration, diapering, and changing
TABLE 4. Hand bacterial counts depending on the day nursing procedures conducted.

\begin{tabular}{ccc}
\hline $\begin{array}{c}\text { The day when } \\
\text { the nursing } \\
\text { procedures were } \\
\text { conducted }\end{array}$ & $\begin{array}{c}\text { No. of } \\
\text { samples }\end{array}$ & $\begin{array}{c}\text { Mean } \pm \text { S.D. } \\
\text { (log cfu/hand) }\end{array}$ \\
\hline 1st day & 28 & $2.68 \pm 0.72$ \\
2nd day & 36 & $2.93 \pm 0.59$ \\
3rd day & 36 & $3.39 \pm 0.82$ \\
4th day & 36 & $3.48 \pm 1.04$ \\
5th day & 36 & $3.11 \pm 0.71$ \\
6th day & 36 & $3.04 \pm 0.76$ \\
\hline
\end{tabular}

positions, for which many samples were collected. As a result of Scheffe's multiple comparison test for each procedure, a significant difference was found in the hand bacterial counts with regard to diapering depending on the day, but no such difference was found with regard to endotracheal aspiration and changing positions depending on the day of care (Table 7).

Comparison of hand bacterial counts depending on the occurrence or non-occurrence of defecation on the day when the procedure was conducted

Figure 2 shows the mean \pm standard deviation of the hand bacterial counts after nursing procedures in the cases where the hand bacterial counts after the nursing procedures were categorized into days when the patient had a bowel movement (the 3rd, 4th, and 6th days), and those when the patient did not (the 1st, 2nd, and 5th day). As a result of the MannWhitney test, no difference was found in the hand bacterial counts after endotracheal aspiration, oral 
TABLE 5. Statistical significance by Scheffe's multiple comparison test.

\begin{tabular}{ccccccc}
\hline \multirow{2}{*}{$\begin{array}{c}\text { The day } \\
\text { nursing } \\
\text { procedures } \\
\text { were conducted }\end{array}$} & \multicolumn{5}{c}{ The day nursing procedures were conducted } \\
\cline { 2 - 7 } & $\begin{array}{c}\text { 1st } \\
\text { day }\end{array}$ & $\begin{array}{l}\text { 2nd } \\
\text { day }\end{array}$ & $\begin{array}{l}\text { 3rd } \\
\text { day }\end{array}$ & $\begin{array}{l}4 \text { th } \\
\text { day }\end{array}$ & $\begin{array}{c}\text { th } \\
\text { day }\end{array}$ & $\begin{array}{c}\text { dh } \\
\text { day }\end{array}$ \\
\hline 1st day & - & - & - & - & - & - \\
2nd day & N.S. ${ }^{b}$ & - & - & - & - & - \\
3rd day & $\mathrm{p}<0.05^{a}$ & N.S. & - & - & - & - \\
4th day & $\mathrm{p}<0.05$ & N.S. & N.S. & - & - & - \\
5th day & N.S. & N.S. & N.S. & N.S. & - & - \\
6th day & N.S. & N.S. & N.S. & N.S. & N.S. & - \\
\hline
\end{tabular}

${ }^{a}$ Statistically significant at $5 \%$.

${ }^{b}$ Not significant.

TABLE 6. Hand bacterial counts depending on the day, after endotracheal aspiration, changing positions, and diapering.

\begin{tabular}{cccc}
\hline $\begin{array}{c}\text { The day when } \\
\text { the nursing } \\
\text { procedures } \\
\text { were conducted }\end{array}$ & $\begin{array}{c}\text { Endotracheal } \\
\text { aspiration } \\
(n=36)\end{array}$ & $\begin{array}{c}\text { Changing } \\
\text { positions } \\
(n=68)\end{array}$ & $\begin{array}{c}\text { Diapering } \\
(n=68)\end{array}$ \\
\hline 1st day & $\begin{array}{c}1.87 \pm 0.58 \\
(n=6)\end{array}$ & $\begin{array}{c}2.74 \pm 0.34 \\
(n=8)\end{array}$ & $\begin{array}{c}3.40 \pm 0.50 \\
(n=8)\end{array}$ \\
2nd day & $\begin{array}{c}2.52 \pm 0.20 \\
(n=6)\end{array}$ & $\begin{array}{c}2.82 \pm 0.59 \\
(n=12)\end{array}$ & $\begin{array}{c}3.03 \pm 0.40 \\
(n=12)\end{array}$ \\
3rd day & $\begin{array}{c}2.54 \pm 0.41 \\
(n=6)\end{array}$ & $\begin{array}{c}2.86 \pm 0.32 \\
(n=12)\end{array}$ & $\begin{array}{c}3.81 \pm 0.66 \\
(n=12)\end{array}$ \\
4th day & $\begin{array}{c}2.38 \pm 0.33 \\
(n=6)\end{array}$ & $\begin{array}{c}3.01 \pm 0.74 \\
(n=12)\end{array}$ & $\begin{array}{c}4.28 \pm 0.88 \\
(n=12)\end{array}$ \\
5th day & $\begin{array}{c}2.53 \pm 0.80 \\
(n=6)\end{array}$ & $\begin{array}{c}2.60 \pm 0.32 \\
(n=12)\end{array}$ & $\begin{array}{c}3.62 \pm 0.32 \\
(n=12)\end{array}$ \\
6th day & $2.21 \pm 0.63$ & $2.88 \pm 0.55$ & $3.16 \pm 0.38$ \\
$(n=6)$ & $(n=12)$ & $(n=12)$ \\
\hline Mean \pm S.D. & $2.34 \pm 0.57$ & $2.82 \pm 0.51$ & $3.48 \pm 0.71$ \\
(log cfu/hand) & & &
\end{tabular}

care, and changing positions depending on whether or not the patient defecated, but higher hand bacterial counts were found for bed baths, genital wash, and diapering on the days when there was some bowel movement.

\section{Comparison of hand bacterial counts depending on the nurse}

Table 8 shows the mean \pm standard deviation of the hand bacterial counts depending on the personnel who conducted the nursing procedures, when the same nursing procedures (diapering and changing positions) were conducted. As for the diapering, a slight difference in the bacterial counts on the hands was found depending on the nurse, but with the Mann-Whitney test, no significant statistical difference was found in terms of the personnel who conducted the care with regard to all the data and two kinds of nursing procedures.

The bacterial counts investigation of the patient and the environment surrounding the patient

Table 9 shows the results of general bacteria detected in the environment surrounding the patient and on the patient's skin, from which the samples were collected by the stamp method or the wiping method. According to the stamp method, samples from places not in direct contact with the patient's skin [sheets, the pillow used for changing positions, hospital pajamas (surface)] to samples from places in direct contact with the patient's skin (diaper, inside), patient's skin (right and left palms) showed progressively higher bacterial counts. Furthermore, with regard to the palms, due to numerous general bacteria, 
TABLE 7. Statistical significance by Scheffe's multiple comparison test.

\begin{tabular}{|c|c|c|c|c|c|c|}
\hline \multirow{2}{*}{$\begin{array}{l}\text { The day when } \\
\text { endotracheal } \\
\text { aspiration, } \\
\text { changing } \\
\text { positions and } \\
\text { diapering were } \\
\text { conducted }\end{array}$} & \multicolumn{6}{|c|}{ The day when endotracheal aspiration, changing positions and diapering were conducted } \\
\hline & $\begin{array}{l}\text { 1st day } \\
\text { e.-a. } \\
\text { c.-p. } \\
\text { dia. }\end{array}$ & $\begin{array}{c}\text { 2nd day } \\
\text { e.-a. } \\
\text { c.-p. } \\
\text { dia. }\end{array}$ & $\begin{array}{c}\text { 3rd day } \\
\text { e.-a. } \\
\text { c.-p. } \\
\text { dia. }\end{array}$ & $\begin{array}{l}\text { 4th day } \\
\text { e.-a. } \\
\text { c.-p. } \\
\text { dia. }\end{array}$ & $\begin{array}{c}\text { 5th day } \\
\text { e.-a. } \\
\text { c.-p. } \\
\text { dia. }\end{array}$ & $\begin{array}{l}\text { 6th day } \\
\text { e.-a. } \\
\text { c.-p. } \\
\text { dia. }\end{array}$ \\
\hline $\begin{array}{l}\text { 1st day } \\
\text { e.-a. }{ }^{a} \\
\text { c.-p. }{ }^{b} \\
\text { dia. }{ }^{c}\end{array}$ & - & - & - & - & - & - \\
\hline $\begin{array}{l}\text { 2nd day } \\
\text { e.-a. } \\
\text { c.-p. } \\
\text { dia. }\end{array}$ & $\begin{array}{l}\text { N.S. }{ }^{e} \\
\text { N.S. } \\
\text { N.S. }\end{array}$ & - & - & - & - & - \\
\hline $\begin{array}{l}\text { 3rd day } \\
\text { e.-a. } \\
\text { c.-p. } \\
\text { dia. }\end{array}$ & $\begin{array}{l}\text { N.S. } \\
\text { N.S. } \\
\text { N.S. }\end{array}$ & $\begin{array}{l}\text { N.S. } \\
\text { N.S. } \\
\text { N.S. }\end{array}$ & - & - & - & - \\
\hline $\begin{array}{l}\text { 4th day } \\
\text { e.-a. } \\
\text { c.-p. } \\
\text { dia. }\end{array}$ & $\begin{array}{l}\text { N.S. } \\
\text { N.S. } \\
p<0.05^{d}\end{array}$ & $\begin{array}{c}\text { N.S. } \\
\text { N.S. } \\
p<0.05\end{array}$ & $\begin{array}{l}\text { N.S. } \\
\text { N.S. } \\
\text { N.S. }\end{array}$ & - & - & - \\
\hline $\begin{array}{l}\text { 5th day } \\
\text { e.-a. } \\
\text { c.-p. } \\
\text { dia. }\end{array}$ & $\begin{array}{l}\text { N.S. } \\
\text { N.S. } \\
\text { N.S. }\end{array}$ & $\begin{array}{l}\text { N.S. } \\
\text { N.S. } \\
\text { N.S. }\end{array}$ & $\begin{array}{l}\text { N.S. } \\
\text { N.S. } \\
\text { N.S. }\end{array}$ & $\begin{array}{l}\text { N.S. } \\
\text { N.S. } \\
\text { N.S. }\end{array}$ & - & - \\
\hline $\begin{array}{l}\text { 6th day } \\
\text { e.-a. } \\
\text { c.-p. } \\
\text { dia. }\end{array}$ & $\begin{array}{l}\text { N.S. } \\
\text { N.S. } \\
\text { N.S. }\end{array}$ & $\begin{array}{l}\text { N.S. } \\
\text { N.S. } \\
\text { N.S. }\end{array}$ & $\begin{array}{l}\text { N.S. } \\
\text { N.S. } \\
\text { N.S. }\end{array}$ & $\begin{array}{c}\text { N.S. } \\
\text { N.S. } \\
p<0.05\end{array}$ & $\begin{array}{l}\text { N.S. } \\
\text { N.S. } \\
\text { N.S. }\end{array}$ & - \\
\hline
\end{tabular}

${ }^{a}$ The line shows the result concerning the hand bacterial counts after endotracheal aspiration.

${ }^{b}$ The line shows the result concerning the hand bacterial counts after changing positions.

${ }^{\circ}$ The line shows the result concerning the hand bacterial counts after diapering.

${ }^{d}$ Statistically significant at $5 \%$.

${ }^{e}$ Not significant.

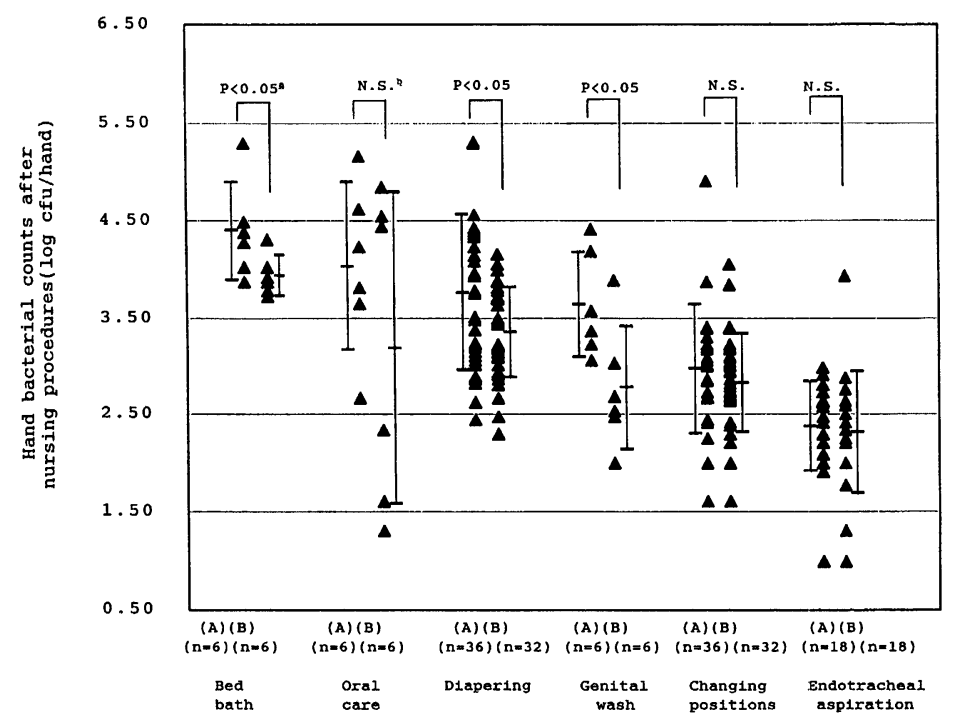

FIG. 2. Hand bacterial counts after nursing procedures categorized into days when there was defecation and those when there was none. The hand bacterial counts after nursing procedures were categorized into days when there was defecation (A) (the 3rd, 4th, and 6th days), and those when there was none (B) (the 1st, 2nd, and 5th day). Symbols $\boldsymbol{\Delta}$ : Value of hand bacterial counts after nursing procedures. Values of mean \pm S.D. are indicated as in Fig.1. ${ }^{a} p<0.05$, Statistically significant at $5 \%$ by Mann-Whitney test ; ${ }^{\circ}$ N.S., Not significant by Mann-Whitney test. 
TABLE 8. Hand bacterial counts depending on the personnel conducting the nursing procedures.

\begin{tabular}{cccc}
\hline $\begin{array}{c}\text { Type of } \\
\text { nursing } \\
\text { procedure }\end{array}$ & $\begin{array}{c}\text { Nurse A } \\
(\log \mathrm{cfu} / \text { hand })\end{array}$ & $\begin{array}{c}\text { Nurse B } \\
(\log \mathrm{cfu} / \text { hand })\end{array}$ & $\begin{array}{c}\text { Statistical } \\
\text { significance }\end{array}$ \\
\hline All the data & $\begin{array}{c}3.25 \pm 0.75 \\
(n=72)\end{array}$ & $\begin{array}{c}3.12 \pm 0.66 \\
(n=64)\end{array}$ & N.S ${ }^{a}$ \\
Changing & $\begin{array}{c}2.81 \pm 0.49 \\
(n=36)\end{array}$ & $\begin{array}{c}2.83 \pm 0.54 \\
(n=32)\end{array}$ & N.S \\
positions & $\begin{array}{c}3.70 \pm 0.71 \\
(n=36)\end{array}$ & $\begin{array}{c}3.40 \pm 0.64 \\
(n=32)\end{array}$ & N.S \\
Diapering & & & \\
\hline
\end{tabular}

${ }^{a}$ Not significant.

measurement through sampling by the stamp method was impossible. In addition, the detected bacterial count (log cfu/hand) in the diaper (inside) according to the wiping method was 4.73. Also those counts from the patient's left and right palms that could not be measured by the stamp method were 6.66 and 6.21 , those from the left and right inguinal regions were 5.62 and 5.73 , and extremely numerous general

TABLE 9. Bacteria detected in the environment surrounding the patient and on the patient's skin.

\begin{tabular}{llc}
\hline Method & \multicolumn{1}{c}{ Sampled location } & $\begin{array}{c}\text { Detected } \\
\text { bacteria }\end{array}$ \\
\hline Stamp & Sheets & $57^{a}$ \\
method & Pillow for changing positions & 36 \\
& Hospital pajamas (surface) & 106 \\
& Diaper (inside) & 209 \\
Patient's skin (left palms) & $<500$ \\
Patient's skin (right palms) & $<500$ \\
& \\
\hline Wiping & Diaper (inside) & $4.73^{b}$ \\
method & 6.66 \\
Patient's skin (left palms) & 6.21 \\
Patient's skin (right palms) & 5.07 \\
Buttocks & 5.62 \\
Right inguinal regions & 5.73 \\
Left inguinal regions & \\
Towel for the bed bath & $3.15,4.28$ \\
1st time & $<1.00,3.36$ \\
2nd time & $1.30,2.51$ \\
3rd time & $1.30,<1.00$ \\
4th time & \\
Toothbrush & 3.46 \\
1st time & 4.39 \\
2nd time & $<1.0$ \\
3rd time &
\end{tabular}

${ }^{a} \mathrm{Cfu} / 10 \mathrm{~cm}^{2}$

${ }^{b} \mathrm{Cfu} / \mathrm{cm}^{2}$ bacteria were detected on the skin surface of the patient. Furthermore, in the mannite salt medium with added yolk, no sample of colonies or around colonies showed response, and no bacterium that might be considered as Staphylococcus aureus was detected from the patient's skin or proximate environment (not shown in Table 9).

In a similar manner, Table 9 shows the results of detection of bacteria from the toothbrush and the towel for the bed bath that were collected by the wiping method. Although the towel for the bed bath was sampled unused immediately before the bed bath was given, the detected bacterial counts (log cfu/hand) were found in the range of less than 1.0 to 4.28 , and heavy contamination was found depending on the day. The toothbrush was sampled before the nursing procedure, and the detected bacterial counts (log cfu /hand) was found in a range of less than 1.0 to 4.39 , and heavy contamination was found depending on the day. Furthermore, with regard to the mannite salt medium with added yolk, there was no sample in which colonies or the area around the colonies showed response, and no bacterium that was considered to be $S$. aureus was detected from the toothbrush or the towel for the bed bath (not shown in table 9).

\section{DISCUSSION}

The nursing procedures focused upon for this study included six types: endotracheal aspiration, diapering, changing positions, bed bath, genital wash, and oral care. The bacterial contamination on hands after the nursing procedures was relatively light. It was considered that one of the reasons for this was that measures such as wearing gloves were taken for nursing procedures for which heavy contamination was expected, including genital wash and endotracheal aspiration (Nystrom, 1994; Steere and Mallison, 1975). There was a tendency for hand bacterial counts to be progressively lower from after bed baths, oral care, diapering, genital wash, changing positions, to after endotracheal aspiration. Based on those results, we concluded that hand bacterial counts after nursing procedures were progressively lower from procedures requiring the nurse's hands to directly touch the patient's skin (or saliva), to those requiring nurses to touch the patient's clothing, etc., to procedures requiring no direct contact with the patient. This accorded well with the previous investigation results (Katsuno et al., 1998; Takahashi, 1999). Likewise, in the bacterial investigation of the patient and his immediate surroundings, the detected bacterial counts went from highest to lowest from samples from patient's skin, places that touch the patient's skin directly, and 
places that do not directly touch the patient's skin. The results were consistent with the hand bacterial counts after the nursing procedures.

Below are the considerations for each nursing procedure. The hand bacterial counts after endotracheal aspiration showed the lowest counts among the nursing procedures conducted, and the contamination on the left hand without the glove was very low in the same manner as that on the right hand with the glove on. Because the endotracheal aspiration is a nursing procedure requiring almost no direct contact with the patient, we considered that not only the gloved hand but also the ungloved one would have light contamination.

The hand bacterial counts after changing positions showed the second lowest count following endotracheal aspiration among the nursing procedures conducted in this study. Gloves were not worn for changing the patient's position, but compared to diapering or bed baths, nurses touch the patient's clothing but don't directly touch the skin. Also for the convenience's sake, the investigation almost each time was conducted on the day following the changing of the sheets and pajamas in the ward, so we considered that contamination by the bacteria from the patient on the clothing or sheets was probably light. The bacterial counts on the pillow for changing positions, sheets, and hospital pajamas collected by the stamp method were approximately $1 / 6$ to $1 / 2 \mathrm{com}$ pared to the amount on the inside of the diapers. For those reasons, it was considered that the hand bacterial counts from the nurses were relatively low.

The hand bacterial counts after diapering were dependent on whether or not the patient defecated on that day. Compared to the case for the outside of the diaper, it is considered that the degree of contamination on the inside of the diaper differs for each procedure, depending on the condition of the soiling in the diaper (whether urination or defecation has taken place), and the timing of the diapering (immediately after urination or defecation, or after some time), etc. At the same time, in addition, with regard to the nurse touching the patient's buttocks during the procedure, the contamination is considered to differ depending on the condition of the diaper, and it is therefore considered that variations are caused in the hand bacterial counts depending on the day of the procedure. The hand bacterial counts after diapering were high following bed baths and, though with slight difference, oral care. This was considered to be caused by the fact that diapering was conducted without gloves, that it requires direct contact with the patient' skin, and that heavy bacterial contamination was possible depending on the condition of the diaper. When diapers are changed, in order to avoid heavy contamination due to the patient's excretions, the nurse wears gloves or tries not to directly touch the excretion with bare hands. However, even if the hands do not touch the excretion directly, the existence of the excretion in the diaper can highly contaminate the patient's buttocks and inside the diaper as well.

Genital wash is performed before diapering, and the hand bacterial counts after genital wash tend to be high when high counts after diapering and bed bath are also detected, and there seems to be no particular relationship with the bacterial counts of other kinds of procedures (changing positions, endotracheal aspiration, and oral care). In addition, the hand bacterial counts after genital wash showed differences depending on whether or not the patient defecated, in the same manner as diapering. Based on those results, it was considered that though genital wash requires nurses to wear gloves, contamination on hands had progressed before putting on the gloves on the days when the patient defecated. That is, during preparation for genital wash, the nurse may have directly touched the inside of the patient's diaper or skin between washing her hands at the completion of the procedure conducted before the genital wash (in this study after the handwashing which followed endotracheal aspiration), and before putting on the gloves. The hand bacterial counts after genital wash seem to be influenced by the condition of the diaper (whether soiling by urination or defecation has occurred, and how long the diaper had been soiled) in the same manner as after diapering. Because of this, it was considered that it would be better in terms of hygiene to wear gloves while preparing for the genital wash, rather than immediately before the genital wash itself. We considered that this could prevent contamination of the environment touched by a nurse during her preparations.

The hand bacterial counts after bed baths were the highest bacterial counts among the counts found in this study. The following were considered to be causes: the nurses directly touch the patient's skin while conducting the bed bath, which could cause the resident bacterial flora loosened from the patient to adhere to the nurse's hands, and the resident bacterial flora adhering to the wet towels for bed baths could get on the nurse's hands via those towels in a similar manner; in addition, because bed baths are given to the whole body, the time for the procedure is relatively long. The hand bacterial counts after bed baths were higher when the patient defecated as in diapering and genital wash. The influence of the condition of the diaper seemed to be a cause, since the nurses opened the diaper to clean the skin inside the 
patient's diaper when giving a bed bath. On the other hand, when the degree of contamination in the unused towels for bed baths was investigated, the results showed that there were cases in which bacterial counts $\left(\mathrm{cfu} / \mathrm{cm}^{2}\right)$ of $1-4$ were detected. Bacterial counts of 3 or greater were detected from three out of eight towels (about 38\%) sampled, and it was suspected that one of the reasons for the greater bacterial counts were the bed bath towels that were themselves contaminated. In the present investigation, no methicillin-resistant Staphylococcus aureus (MRSA) that could cause a nosocomial infection was detected from the skin of the patient of this study. However, when bed baths are given to patients carrying MRSA on their skin, it is predicted that a great amount of MRSA could adhere to the nurse's hands. Based on these considerations, we thought that wearing gloves is necessary for bed baths, or that care should be taken to completely remove contaminants adhering to hands by handwashing.

The hand bacterial counts after oral care were relatively high among the counts found after nursing procedures conducted in this study. There are cases both in which gloves were worn and not worn in the oral care procedure. Because there is not much data for the cases where the gloves were worn, statistical analysis was not performed, but the bacterial counts on the hands when the gloves were worn were very low, which leads us to believe that the influence of the gloves was great. As a cause for the detection of high hand bacterial counts when the gloves were not worn, contamination on the handle of the toothbrush held by the nurse during the procedure was considered. To confirm this, bacterial collection was performed from the handle of the toothbrush, and there were cases in which counts of 3-4 $\log \mathrm{cfu} / \mathrm{cm}^{2}$ were found; thus, bacterial adhesion from the contaminated handle was considered to be a cause. However, depending on the day, there were cases in which 3-4 $\log \mathrm{cfu} / \mathrm{cm}^{2}$ of hand-carried bacterial counts were detected after oral care even when there was hardly any detected from the handle, so it seemed that not only the toothbrush itself was the cause.

In this study, it was suggested that the hand bacterial counts after nursing procedures were highest for procedures involving direct contact with the patient's skin (or saliva), lower for procedures touching his clothing, etc., and lowest for procedures involving no direct contact with the patient.

\section{REFERENCES}

Casewell, M., and Phillips, I. (1977) Hands as route of transmission for Klebsiella species. Br. Med. J., 19, 1315-1317.

Chamberlain, A.N., Halablab, M.A., Gould, D.J., Miles, R.J. (1997) Distribution of bacteria on hands and the effectiveness of brief and thorough decontamination purocedures using non-medicated soap. Zentralb. Bakteriol., 285, 565-575.

Jiang, X. (1998) Pathogen transmission in child care settings studied by using a cauliflower virus DNA as a surrogate maker. J. Infect. Dis., 177, 881-888.

Katsuno, K., Fukuyama, Y., Urata, H. (1998) Pollution situation of fingers in nursing of patients with MRSA infection. Comparison according to nursing care (in Japanese). Jpn. J. Nursing Arts, 4, 313-317.

Nystrom, B. (1994) Impact of Handwashing on mortality in intensive care: Examination of the evidence. Infect. Control. Hosp. Epidemiol., 15, 435-436.

Steere, A.C., and Mallison, G.F. (1975) Handwashing practices for the prevention of nosocominal infections. Ann. Int. Med., 83, 683-690.

Takahashi, Y., Taya, C., Hashimoto, T., Sakuma, J., Uno, M., Yamashita, T. (1994) Contamination of nurses' protective gowns and gloves after various cares for MRSA infected patients (in Japanese). Jpn. J. Nursing Res., 27, 30-36.

Takahashi, Y. (1999) Bacterial survival on nurses' fingers after handwashing with soap and water following nursing cares for critical patients (in Japanese). Jpn. J. Nursing Res., 32, 65-71.

Tanada, S., Kitakoji, M., Nakamura, T., Kawasaki, N. (1996) Microbiological evaluation of hand pollution after nursing care (in Japanese). Med. Biol., 133, 127-130. 